九州大学学術情報リポジトリ

Kyushu University Institutional Repository

\title{
Purification and Characterization of Chymotrypsin Inhibitor CI-3 from Hemolymph of Si lkworm, Bombyx mori
}

Zhao, Qialing

Sericultural Research Institute, Chinese Academy of Agricultural Sciences

He, Ningjia

Institute of Genetic REsources, Faulty of Agriculture, Kyushu University

Shirai, Koji

Institute of Genetic REsources, Faulty of Agriculture, Kyushu University

Fujii, Hiroshi

Institute of Genetic REsources, Faulty of Agriculture, Kyushu University

他

https://doi.org/10.5109/4569

出版情報: 九州大学大学院農学研究院紀要. 49 (1)，pp.93-99，2004-02-01. Faculty of Agriculture， Kyushu University

バージョン :

権利関係 : 
J. Fac. Agr., Kyushu Univ., 49 (1), 93-99 (2004)

\title{
Purification and Characterization of Chymotrypsin Inhibitor CI-3 from Hemolymph of Silkworm, Bombyx mori
}

\author{
Qiaoling ZHAO ${ }^{1}$, Ningjia HE$^{2}$, Koji SHIRAI ${ }^{2}$, Hiroshi FUJII ${ }^{2 *}$, \\ Yutaka BANNO ${ }^{2}$, and Kohji YAMAMOTO ${ }^{2}$ \\ Institute of Genetic Resources, Faulty of Agriculture, \\ Kyushu University, Fukuoka 812-8581, Japan \\ (Received October 31, 2003 and accepted November 14, 2003)
}

\begin{abstract}
The chymotrypsin inhibitor 3 (CI-3) whose expression is controlled by Ict-E gene on the 22nd linkage group was purified from the larval hemolymph of silkworm Bombyx mori by combination of a series of column chromatography and polyacrylamide gel electrophoresis in the presence of sodium dodecyl sulfate (SDS-PAGE). The molecular weight of CI-3 was $40 \mathrm{kDa}$ and its isoelectric point was 5.5. The results of analysis on the protein properties revealed that the inhibitory activity of CI-3 against $\alpha$-chymotrypsin was remarkably stable at $\mathrm{pH} 6.9-10.6$, but lost $30 \%$ and $70 \%$ of the inhibitory activity at $\mathrm{pH} 5.9$ and $\mathrm{pH} 11.9$, respectively. CI-3 was quite stable at the temperature between $0^{\circ} \mathrm{C}$ to $50^{\circ} \mathrm{C}$ and lost inhibitory activity completely at the temperatures higher than $60^{\circ} \mathrm{C}$. CI-3 showed strong inhibitory activity toward $\alpha$-chymotrypsin and silkworm digestive juice (DJ) protease.
\end{abstract}

Key Words: Bombyx mori; hemolymph; chymotrypsin inhibitor; protein purification

\section{INTRODUCTION}

Protease inhibitors are widely found in animals, plants and microbes (Sato and Murano, 1973; Yoshimoto and Laskowski, 1982; Brizin et al, 1984; Taguchi et al, 1994). They have recently been extensively studied since they involved in regulation of other functional proteins, protection tissues from harmful proteases and prevention of invading proteases (Kurioka et al, 1999; Yoshimoto et al, 1982; Narayanaswamy et al, 1988).

According to the electrophoretic mobility in polyacrylamide gel, there are at least 16 chymotrypsin inhibitors (CIs) in the larval hemolymph of silkworm, Bombyx mori. These CIs are classified into three groups and are controlled by Ict-A, Ict-D, and Ict-E genes located on the 2nd, 19th and 22 nd linkage group, respectively (Fujii et al., 1989, 1996a; Deng et al., 1990; Shinohara et al., 1993). The first group including CI-9, -10, -13, -13 , $-1,-2,-2$ ', -b1 and -b2, controlled by Ict- $A$ gene, is Kunitz-type CIs with low molecular weight. While the Ict-D gene is responsible for the production of CI-6, -7 , and -8 which are Serpin-type CIs with an oligosaccharide chain and molecular mass of $42 \mathrm{kDa}$. (Shirai et al., 1997). These protease inhibitors have been purified, characterized, and the studies on their functions are in progress. It is worthwhile to note that the genomic structures of CI-13 and CI-b1 have been clarified and CI-b1 was confirmed as an immune-related gene (He et al., 2003). In addition, it was found that CI-8, once secreted

\footnotetext{
1 Sericultural Research Institute, Chinese Academy of Agricultural Sciences, Zhenjiang 212018, China;

2 Institute of Genetic Resources, Faulty of Agriculture, Kyushu University, Fukuoka 812-8581, Japan

* Corresponding author (E-mail: fujii@agr.kyushu-u.ac.jp)
} 
into hemolymph, was sequestered into the fat body again after the onset of spinning (Shirai et al., 2000). Moreover, the receptors of CI-8, which were expressed in the midgut of silkworm during metamorphosis, were identified and purified in our laboratory (data unpublished). CIs referred to as CI-3 and CI-4 belonging to the third group are controlled by the Ict-E gene mapped to the starting position of the $22^{\text {nd }}$ linkage group (Fujii et al., 1996b). Our previous studies of 400 silkworm B. mori stains preserved in Kyushu University demonstrated that every strain contains CI-3 or CI-4 or both. It indicated that CI-3 and CI-4 are essential components and play important roles during the life of silkworm. In the present study, CI-3 was purified and characterized as a first step toward the elucidation of its physiological functions.

\section{MATERIALS AND METHODS}

\section{Insects and hemolymph}

Silkworm strain, B. mori, used in this study is e01 preserved in the Institute of Genetic Resources, Faulty of Agriculture, Kyushu University. The larvae were reared on mulberry leaves. Hemolymph collected from larvae on day 4 of the $5^{\text {th }}$ instar was centrifuged at $3,000 \mathrm{~g}$ for 10 minutes at $4^{\circ} \mathrm{C}$ to remove hemocytes. The resultant hemolymph was mixed with a trace of phenylthiourea and stored at $-20^{\circ} \mathrm{C}$ until to be used.

\section{Zymogram for CIs}

In the detection of CIs activity by zymogram, samples were electrophoretically separated. Gels were then incubated with $\alpha$-chymotrypsin solution, and stained by protease substrate $N$-acetyl-D, L-phenylalanine- $\beta$ - naphthylester dissolved in $\mathrm{N}$, N'-dimethylformamide and tetrazotized orthodiamisidine (Sigma, Inc.).

\section{Purification of CI-3}

Hemolymph was fractionated by salting out with ammonium sulfate solution between 30 to $85 \%$ saturation. Precipitates were dissolved in $50 \mathrm{mM}$ Tris- $\mathrm{HCl}(\mathrm{pH} \mathrm{7.0)}$ and dialyzed overnight against the same buffer with $20 \%$ saturation of ammonium sulfate. Dialysate was loaded onto a Butyl Toyopearl $650 \mathrm{M}$ column $(2.0 \times 35 \mathrm{~cm})$ equilibrated with the same buffer. The column was firstly washed at $4{ }^{\circ} \mathrm{C}$ to remove the non-adsorbed proteins, then followed by linear gradient elution with ammonium sulfate from $20 \%$ to $0 \%$ to dissolve the adsorbed proteins. Inhibitor-containing fractions of target proteins were collected and applied to chromatography on a DEAE Sepharose column $(1.5 \times 40 \mathrm{~cm})$ that have been equilibrated with $50 \mathrm{mM}$ Tris- $\mathrm{HCl}(\mathrm{pH} \mathrm{7.0)}$. The adsorbed proteins were eluted with a linear gradient of sodium chloride from 0 to $3 \mathrm{M}$. Active fractions were combined and dialyzed overnight against $1 \mathrm{mM}$ phosphate buffer (PB). Samples were then loaded into a hydroxylapatite column and eluted with $\mathrm{PB}$ of increasing concentration from $1 \mathrm{mM}$ to $0.5 \mathrm{M}$ to dissolve the adsorbed proteins. CI activity was monitored by native-PAGE and followed by zymogram throughout the purification steps.

\section{Electrophoresis and recovery of target protein}

The above protein sample was loaded onto $12 \%$ polyacrylamide gel in the presence of sodium dodecyl sulfate for electrophoresis (Laemmli, 1970). The pieces of gel with the 
target protein were cut down and the proteins were eluted by an electro-eluter. Protein concentration was determined by the Lowry's method using bovine serum albumin as a standard (Hayashi, 1983).

\section{Determination of isoelectric point and molecular mass}

Two-dimensional polyacrylamide gel electrophoresis (2D/PAGE) was carried out for determination of isoelectric point and molecular mass. The immobilized electrolyte used in the first isoelectric focusing was Immobiline ${ }^{\mathrm{TM}}$ Drystrip of $\mathrm{pH} 3-10$ and $18 \mathrm{~cm}$ in size. The second electrophoresis was done in a 15\% SDS-PAGE. For isoelectric point (pI) calibration, a mixture of proteins with a $\mathrm{pI}$ value from 5.1 to 7.1 was used as markers. The molecular mass markers used were phosphorylase $b(97 \mathrm{kDa})$, bovine serum albumin $(66 \mathrm{kDa})$, ovalbumin $(45 \mathrm{kDa})$, carbonic anhydrase $(30 \mathrm{kDa})$, soybean trypsin inhibitor $(20.1 \mathrm{kDa})$ and $\alpha$-lactalbumin $(14.4 \mathrm{kDa})$ purchased from Amersham Pharmacia Biotech Co. Ltd.

\section{Assay of inhibitory activity of CI-3}

Inhibitory activity against chymotrypsin was measured by the method using casein as substrate, described by Fujii (Fujii et al., 1989). One unit of inhibitory activity was defined as the amount of inhibitor required for the complete inhibition of 400 pmoles $\alpha$-chymotrypsin. The effects of temperature and $\mathrm{pH}$ on the inhibitory activity were also examined by the method previously reported (Fujii et al., 1989). In each inhibitory reaction for effects of $\mathrm{pH}$ on the stability of CI-3, $100 \mu \mathrm{l}$ CI-3 solution containing $2.5 \mathrm{U}$ of inhibitory activity was incubated with $40 \mu \mathrm{l}$ buffers of different $\mathrm{pH}$. Citrate-phosphate buffer was used for $\mathrm{pH} 3.0$ to $\mathrm{pH} 7.0$, Tris-HCl buffer for 7.0 to 9.0 and glycine-NaOH buffer for 9.0 to 11.0. The residual inhibitory activities of CI-3 were measured after incubating for 24 hours at $4{ }^{\circ} \mathrm{C}$ in the indicated buffers. For effects of temperature on the stability of CI-3, in each reaction $2.5 \mathrm{U}$ CI-3 solution was mixed with $40 \mu \mathrm{l} 50 \mathrm{mM}$ Tris-HCl (pH 7.4) and kept under different temperature for 30 minutes before measurement of the residual inhibitory activity. Specificity of CI-3 against various proteases was investigated by the method previously reported (Fujii et al., 1989). The proteases used in this study were $\alpha$-chymotrypsin (EC 3.4.21.1), trypsin (EC 3.4.21.4), ficin (EC 3.4.22.3), carboxypetidase A (EC 3.4.17.1), V8 proteinase (EC 3.4.21.19), and Serratia peptidase from Serratia sp. All of these proteases were obtained from Sigma (Sigma, Inc.). Digested juice was collected from the 5 th instar larvae.

\section{Sequencing of $\mathbf{N}$-terminal amino acid residues of $\mathbf{C I}-3$}

After electrophoresis on 10\% SDS-polyacrylamide gel, CI-3 protein was transferred to a PVDF membrane. The pieces corresponding to CI-3 were prepared and then submitted to analysis. Sequences of $\mathrm{N}$-terminal amino acid residues were determined by automated Edman degradation (Edman and Begg, 1967)

\section{RESULTS AND DISCUSSION}

According to the previous research, the most poorly understood chymotrypsin inhibitors presented in silkworm hemolymph are CI-3 and CI-4. In this research, we have 
used the e01 strain of $B$. mori which has CIs-3, $6,7,8$, and 13 in the hemolymph to isolate CI-3. Through four-step procedure as described in Materials and Methods, the final preparation showed one protein band on SDS-PAGE followed by silver staining (Fig. 1). This result indicated that CI-3 was highly purified. The proteins were combined, lyophilized and stored at $-20^{\circ} \mathrm{C}$ as purified CI-3 for consequent analysis.

2-D electrophoresis was carried out to determine the molecular weight and isoelectric point of $\mathrm{CI}-3$. As shown in Fig. $2 \mathrm{~A}$ and $2 \mathrm{~B}$, the molecular weight and pI of CI-3 have been analyzed and compared with those of several markers. From the two curves, CI-3 was estimated to be a protein of approximately $40 \mathrm{kDa}$ and $\mathrm{pI}$ of 5.5 .

Purified CI-3 was stable below $37^{\circ} \mathrm{C}$ in neutral pH buffer (Fig. 3A). CI-3 retained nearly $60 \%$ of its antichymotrypsin activity after $30 \mathrm{~min}$ of heat treatment at $50^{\circ} \mathrm{C}$, whereas this inhibitor lost most of its antichymotrypsin activity after heat treatment at the temperatures higher than $60^{\circ} \mathrm{C}$. Among the purified chymotrypsin inhibitors presented in silkworm hemolymph, CI-3 showed similar thermal stability to CI-8 and lower stability than Kunitz-type CIs such as CI-13 and CI-b1(Shirai et al, 1997; Fujii et al., 1989). The effects of $\mathrm{pH}$ were also investigated at $4^{\circ} \mathrm{C}$. As shown in Fig. 3B, CI-3 was remarkably stable at $\mathrm{pH}$ of 6.9 to 10.6 . However, it retained 70 and $30 \%$ of its antichymotrypsin activity at $\mathrm{pH} 5.9$ and 11.9, respectively. This result indicated that CI-3 were easily inactivated in alkaline $\mathrm{pH}$ as well as in acidic $\mathrm{pH}$.

The purified CI-3 was tested against some serine proteases and the crude protease isolated from larval digestive juice, as listed in Table 1. The CI-3 presented an inhibitory activity towards $\alpha$-chymotrypsin, proteases from digestive juice, and very weak activity against ficin. Contrast to these, it can not inhibit trypsin, carboxypetidase A, V8 pro-

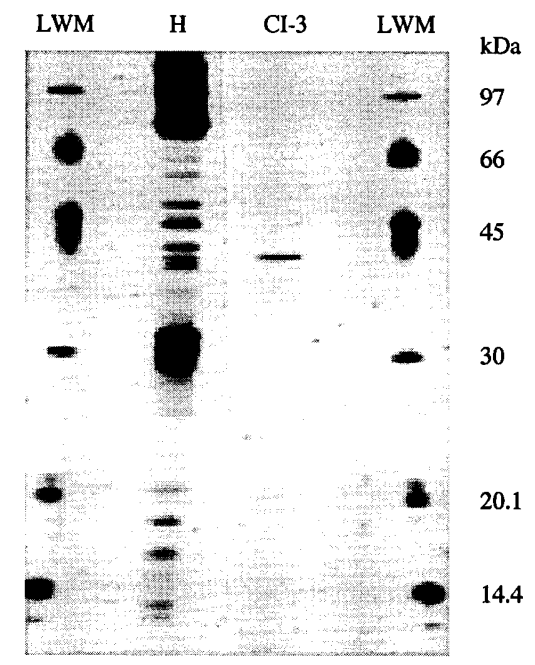

Fig. 1. SDS-PAGE of the purified CI-3. H represents the hemolymph and LWM is the size markers. 


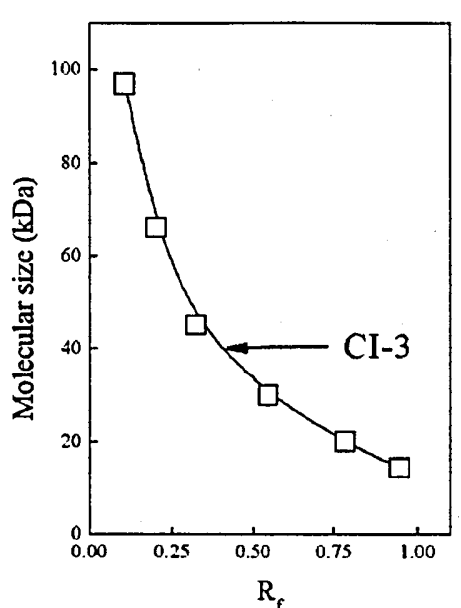

A

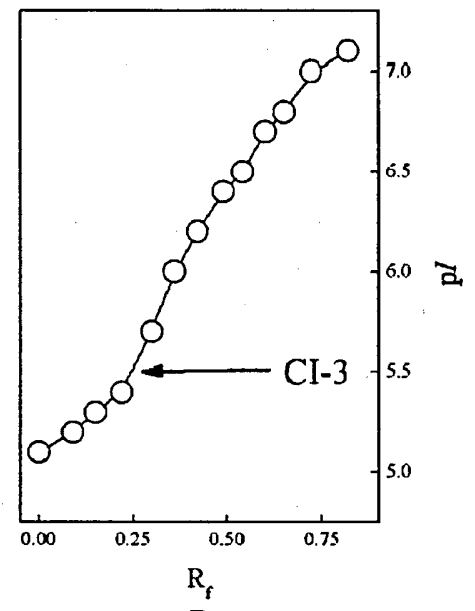

B

Fig. 2. Determination of molecular weight and pI of Cl-3. (A) Phosphorylase b $(97 \mathrm{kDa})$, bovine serum albumin $(66 \mathrm{kDa})$, ovalbumin $(45 \mathrm{kDa})$, carbonic anhydrase $(30 \mathrm{kDa})$, soybean trypsin inhibitor $(20.1 \mathrm{kDa})$ and $\alpha$-lactalbumin ( $14.4 \mathrm{kDa}$ ) were used as size standards. (B) A mixture of proteins with a pI value from 5.1 to 7.1 was used as isoelectric point markers. The arrows indicate the molecular weight and pI of CI-3.

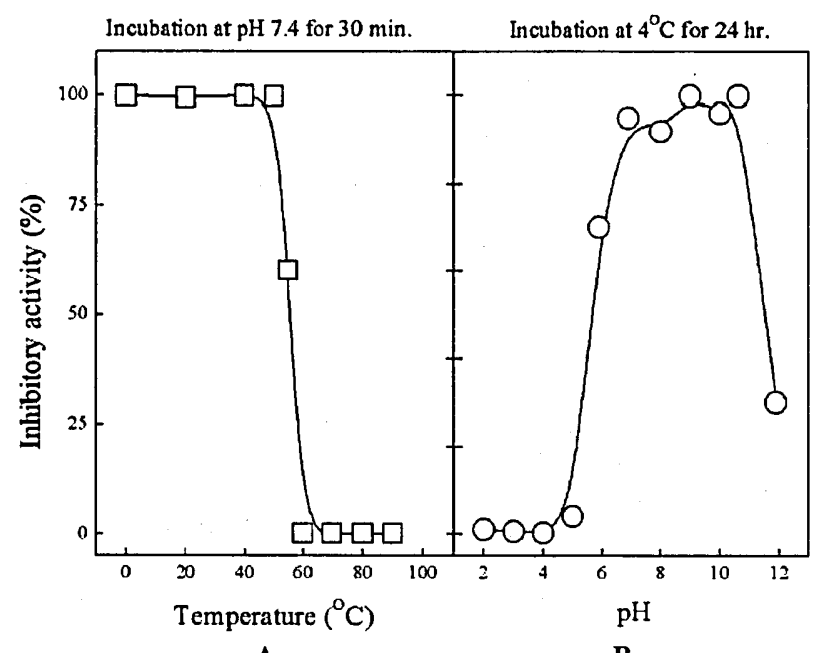

A

B

Fig. 3. Effects of temperature and $\mathrm{pH}$ on the stability of the purified $\mathrm{CI}-3$. (A) Effects of temperature on the stability of CI-3. Foe each test, 2.5 units of CI-3 was used. Results were expressed as the percentages of the activity at $4^{\circ} \mathrm{C}$. (B) Effects of $\mathrm{pH}$ on the stability of CI-3. For each test, 2.5 units of CI-3 was used. CI activity was measured after incubating for 24 hours at $4^{\circ} \mathrm{C}$ at the indicated pHs. 
teinase, and Serratia peptidase from Serratia sp.

The N-terminal amino acid sequences of CI-3 has been determined and resulted in a sequence up to 20 residues, 'AVTNLSNVLKNGNDNFTARM ${ }^{20}$. We compared these partial sequences of CI-3 with those of other protease inhibitors available in Database. The search result showed that the N-terminal amino acid sequences of CI-3 are identical with those of antitrypsin and antichymotrypsin, and demonstrated that CI-3 might belong to the serpin family (Sasaki, 1991). Since CI-3 can inhibit $\alpha$-chymotrypsin specifically, it seems to show that CI-3 is a counterpart of antichymotrypsin. Future studies will involve cloning the gene of CI-3 that can allow us to identify the total sequence of this chymotrypsin inhibitor.

Table 1. Specificity of CI-3 against various proteases. 2.5 units of CI-3 were used for each measurement. The inhibitory activity was expressed in percentages of inhibitory activity against chymotrypsin.

\begin{tabular}{lc}
\hline Protease & Relative inhibitory activity (\%) \\
\hline$\alpha$-chymotrypsin & 100.0 \\
trypsin & 0.0 \\
ficin & 2.9 \\
Carboxypeptidase A & 0.0 \\
V8 proteinase & 0.0 \\
Serratia peptidase & 0.0 \\
B. mori digestive juice protease & 94.1 \\
\hline
\end{tabular}

\section{ACKNOWLEDGEMENT}

We are grateful to M. Nakamura (National Institute of Sericultural and Entomological Science, Tsukuba, Japan) for N-terminal amino acid sequencing. This work is supported by National Bio-resources Project (RR2002) from the Ministry of Education, Science and Culture of Japan.

\section{REFERENCES}

Brizin, J., T. Popuic and V. Tunk 1984 Human cystatin, a new protein inhibitor and cysteine proteinase. Biochem. Biophys. Res. Commun., 118: 103-109

Deng, L. R., H. Fujii, H. Aratake, Y. Kawaguchi, and K. Koga 1990 Isolation and properties of two allelic chymotrypsin inhibitors from the hemolymph of the silkworm, Bombyx mori. Insect Biochem., 20: 531-536

Edman, P., and G. Begg, 1967 Automated equipment for sequence determinations. Eur. J. Biochem., 1: 80-91

Fujii, H., H. Aratake, L. R. Deng, M. Nakamura, Y. Kawaguchi and B. Sakaguchi 1989 Purification and characterization of novel chymotrypsin inhibitor controlled by the silkworm, Bombyx mori. Comp. Biochem. Physiol., 94B: 149-155

Fujii, H., H. Aratake, H. Doira and K. Koga 1996a Genetic analysis of chymotrypsin inhibitors in the hemolymph of Bombyx mori. J. Seric. Sci. Jpn., 65: 334-341

Fujii, H., H. Aratake and H. Doira 1996b Genetic analysis of hemolymph chymotrypsin inhibitor-3 and 4 in the silkworm, Bombyx mori. J. Seric. Sci. Jpn., 65: 385-389

Hayashi H. 1983 A filter paper technique for the micro detemination of protein. Seikagaku, 55: 
257-258. (in Japanese)

He, N. J., M. Yakiyama, H. Fujii, Y. Banno and K. Yamamoto 2003 Genomic structure and expression analysis of the gene encoding a silkworm basic Kunitz-type chymotrypsin inhibitor. Biochem. Biophys. Acta., 1628: 71-77

Kurioka A, M. Yamazaki and H. Hirano 1999 Primary structure and possible functions of a trypsin inhibitor of Bombyx mori. Eur. J. Biochem., 259(1-2): 120-126

Laemmli, U, K. 1970 Cleavage of structural proteins during the assembly of the head of bacteriophage T4. Nature, 227: 680-685

Narayanaswamy, R. S. Manickam and E. M. John 1988 Purification and characterization of two trypsin inhibitors from the hemolymph of Manduca sexta larvae. J. Biol. Chem., 263(23): 11523-11527

Sasaki, T., 1991, Patchwork-structure serpin from silkworm (Bombyx mori) larval hemolymph. Eur. J. Biochem., 202(2): 255-261

Sato, S. and S. Murao (1973): Isolation and crystallization of microbial alkaline protease inhibitor, S-SI. Argic. Bio. chem., 37: 1067-1074

Shinohara, T., Y. Aso, K. Shirai, H. Fujii and G. Funatsu 1993 Purification of chymotrypsin inhibitors from larval hemolymph of the silkworm, Bombyx mori. Biosci. Biotech. Biochem., 57: 1067-1071

Shirai, K., H. Fujii and H. Doira 1997 Purification and characterization of a chymotrypsin inhibitor with an oligosaccharide chain from the hemolymph of Bombyx mori. J. Seric.Sci. Jpn., 66: 253-260

Shirai, K., H. Fujii, H. Doira and H. Iwamoto 2000, Synthesis and resorption of a humoral chymotrypsin inhibitor, CI-8, by fat body of the silkworm, Bombyx mori. Insect Biochem and Molec. Bio., 30: 363-368

Taguchi, S., S. Kojima, M. Terabe, K. Miura and H. Momose 1994 Comparative studies on the primary structures and inhibitory properties of subtilisin-trypsin inhibitors from Streptomyces. Eur. J. Biochem., 220(3): 911-918

Yoshimoto, M. and M. Sr. Laskowski 1982 Large scale purification of isoinhibitors of trypsin from swine colostrum using zinc chelate chromatography and chromatofocusing. Preparative Biochem., 12: 235-254 